\title{
Corporate Communication Strategy in Creating The Awareness of The Covid-19 Through Instagram
}

\author{
Saras Ayunarinia ${ }^{\mathrm{a}, 1}$ and Santi Delliana $\mathrm{a}^{\mathrm{b}, 2, *}$ \\ ${ }^{\mathrm{a}, \mathrm{b}}$ Institut Teknologi dan Bisnis Kalbis \\ Email: ${ }^{1}$ sayunarini@gmail.com; ${ }^{2}$ anastasia.santi@kalbis.ac.id* \\ *corresponding author
}

\begin{abstract}
Keywords:
communication strategy, new media, socialization, Instagram, Cutlip, and center theory.
\end{abstract}

\begin{abstract}
Following its mission, PT Kereta Commuter Indonesia continues to provide rail transportation services amid the Covid-19 spread in Indonesia. One of the communication strategies implemented by PT. Kereta Commuter Indonesia communicates directly through new media is @commuterline Instagram account using the hashtag \#KCILawanCorona to anticipate the spread of the Covid-19. The study aims to determine PT Kereta Commuter Indonesia's communication strategy in preventing the spread of the Covid-19. This study used the descriptive qualitative method. This study will increase awareness based on the Cutlip and Center Theory and help the public in anticipating the spread of the Covid-19. This research is the communication strategy of PT Kereta Commuter Indonesia includes four steps to solve problems in the Cutlip and Center Theory so that socialization can be accepted and affects commuter line passengers' attitudes. This research includes in-depth interviews, observation, and documentation for data collection. Based on researchers' findings, PT. Kereta Commuter Indonesia implemented a communication strategy in anticipation of the Covid-19 spread. According to the Cutlip and Center Theory written by Broom and Sha (2013), the communication strategy applied is related to the four-step problem-solving process. It has research results, namely to protect internal and external parties of PT. Kereta Commuter Indonesia, provide education, and give appeal to the public, especially commuter line passengers to be more aware, be alert and care to anticipate the spread of the Covid-19.
\end{abstract}

Copyright (C) 2021 Channel Jurnal Komunikasi. All right reserved.

\section{INTRODUCTION}

At the end of December 2019, Covid-19, or the Covid-19, was first discovered in Wuhan, China. This virus infects mild to severe symptoms of the respiratory system. It spreads very easily and quickly, namely through fluids that come out of the patient's body. Spread can occur when close direct contact with sufferers is exposed to and inhaled fluids from the patient's body through sneezing or coughing. Some of the symptoms caused to sufferers include coughing, shortness of breath, dry throat, fever with a body temperature reaching 38 degrees Celsius (Alodokter, 2021).

The Covid-19 has spread to several countries, including Indonesia. President Joko Widodo announced the first case of Covid-19 infection on March 2, 2020. The president appointed a spokesman for the management of the Covid-19 for Indonesia, Achmad Yurianto. The beginning of the spread of the virus in Indonesia was when a foreigner from Japan and a female citizen (31 years) made direct contact while at a South Jakarta restaurant. The first patient, an Indonesian citizen (31 years old), tested positive for the Covid-19, then transmitted the virus to his mother (64 years) due to close contact to care for his child. The spread of the Covid-19 in Indonesia is straightforward and fast, so that the number of victims continues to increase (Dewi, 2020).

According to Law Number 24 of 2007 concerning disaster management, the Government has imposed social distancing rules (Undang-Undang Republik Indonesia Nomor 24 Tahun 2007, n.d.). Jakarta Governor Anies Baswedan officially implemented the PSBB policy on homework, research, and worship on April 10, 2020. The governor implemented this policy to stop the spread of the Covid-19. However, not all companies can implement these regulations because many workers are forced to work. Those who are still working use public transportation, especially the Commuter Line (Aulia, 2020). 
Commuter Line users who continue to work certainly have fears and worries about traveling, especially using public transportation. Crowds and crowds have a high risk of being an intermediary for the spread of the virus - however, PT. Kereta Commuter Indonesia is trying to continue operating and providing services and conducting socialization to anticipate the Covid-19's spread. The socialization was carried out by PT Kereta Commuter Indonesia in various ways and using social media @commuterline Instagram account. Commuter Line is one of the most frequently used public transportation daily. Reaching the JABODETABEK area and its surroundings and having low fares makes the Commuter Line one of the most effective transportation. The calls for social distancing and Work From Home policy caused PT Kereta Commuter Indonesia's customers to drop 27 percent, as reported by VP PT Kereta Commuter Indonesia (KCI) Anne Purba in a press release on Monday, March 16, 2020.

Since the spread of the Covid-19, which continues to experience an increase in the number of sufferers, PT Kereta Commuter Indonesia has created a communication strategy to disseminate the anticipation of the Covid-19's spread to its users. On February 2, 2020, socialization was carried out in anticipation of the spread of the Covid-19 by providing education to users at Tanah Abang Station, Bogor Station, Juanda Station, and several stations to wash their hands using soap properly and provide free masks. They were conducting a campaign to anticipate the Covid-19's spread using banners in the station area. They also reminded all users through the announcers in each train car to keep them clean. Additional efforts they are doing are by distributing free masks to sick users, providing hand sanitizers in train cars, providing portable sinks, giving signs with a distance of 1 meter at all points in the station area and inside train cars, enforcing body temperature checks for each user who will log in, and enforces mandatory rules to use masks for each user. During the pandemic, the Covid-19 can also be called an obedient crisis phase (Sari \& Nugrahani, 2019, p. 94) is the phase where the crisis is happening. The continuity of the crisis depends on the internal parties facing it.

Minister of State-Owned Enterprises (BUMN) Erick Thohir also implemented social distancing and physical distancing according to President Joko Widodo's policies in preventing the spread of the Covid-19 (Hairami, 2020). This policy applies to all companies under the Ministry of State-Owned Enterprises, especially those related to public services. DKI Jakarta Governor Anies Baswedan's PSBB policy, which was implemented on April 10, 2020, has changed the commuter line's work from 06.00 to 18.00 WIB. New Commuter Line users can enter the DKI Jakarta area at 06.00 WIB and leave the DKI Jakarta area until 18.00 WIB. PT Kereta Commuter Indonesia hopes to support efforts to prevent the Covid-19's spread by following government policies.

PT Kereta Commuter Indonesia also conducts socialization to anticipate the Covid-19's spread by uploading @ commuterline Instagram account with the hashtag \#KCILawanCorona in the form of posts, stories, and also IG TV to provide education, information and conduct socialization campaigns to anticipate the spread of the Covid-19. There is information regarding the mandatory rules for wearing masks through the Instagram post when in the station area according to the regulations made by the Governor of DKI Jakarta No. 9 of 2020. Signs with a distance of 1 meter at each point in the station area and inside train cars. Additionally, the maximum number of passengers in a train series is limited to 60. Information regarding the adjustment of Commuter Line operating hours has been determined since the enactment of the PSBB on April 10, 2020 (Fitriani, 2020). They are also aggressively conducting campaigns regarding the anticipation of the spread of the Covid-19. They also prioritized passengers to wash their hands with soap and running water through a portable sink.

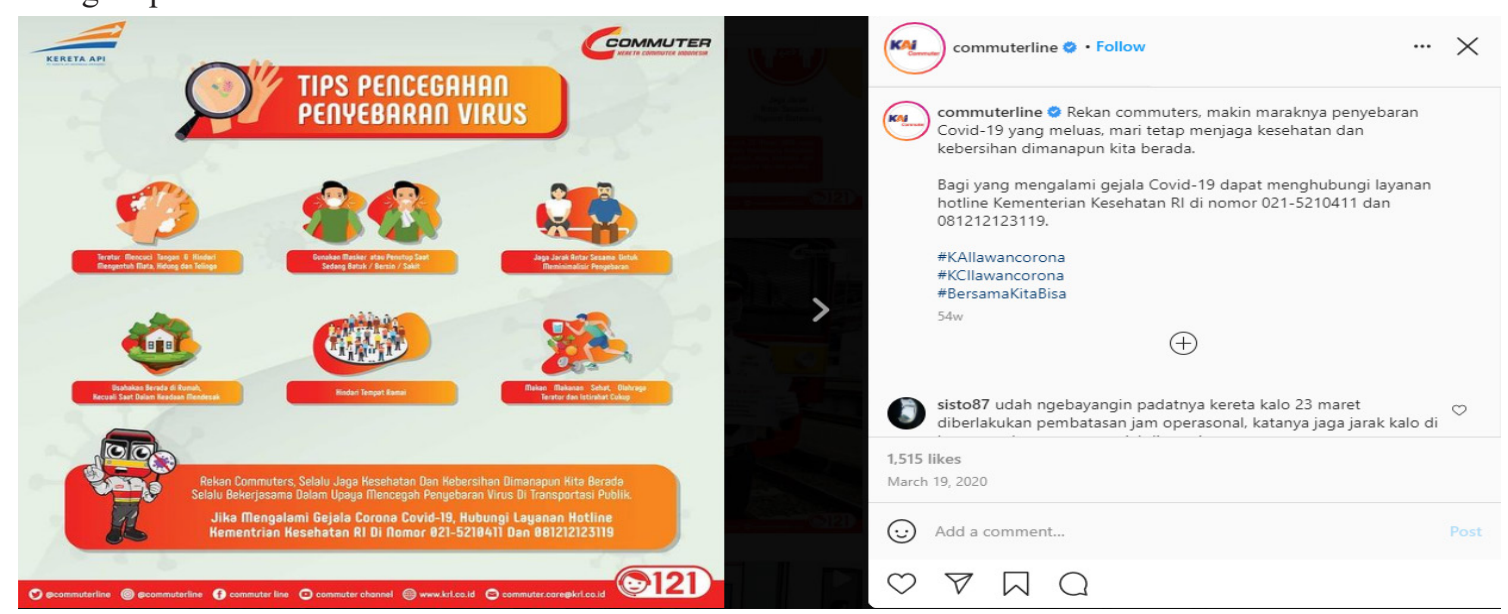

Fig. 1 Tips for Preventing the Spread of Viruses

Source: (Commuterline Instagram Account, 2020)

Based on the research topic that has been explained, the formulation of this research's problem is how to implement the socialization of the anticipation of the spread of the Covid-19 by PT Kereta Commuter Indonesia. 
THE PROPOSED METHOD

A. Cutlip and Center Theory

Cutlip and Center say in Broom \& Sha (2013, p. 263), (Maharani \& Siahaya, 2016, p. 28) the most sustainable forms of public relations are the scientifically managed part of the problem solving and organizational change process. Public relations practitioners use the best theory and evidence available in a four-step problem-solving process:

1. Define the problem or opportunity. This first step determines "What happened?" which creates the perception of something untrue or fixable. It checks and monitors the knowledge, views, attitudes, and behaviors concerned internally and externally and is influenced by measures and policies for all other steps in the problem-solving process.

2. Planning and scheduling. The first step is to gather information to strategically decide on program objectives, shared goals, objectives, actions, and communications. This section contains findings from initial organizational policies and programs. This second step answers, "What should we change or do to solve problems or seize opportunities based on what we learned about the situation?"

3. Take action and communicate. The third step involves a program of action and communication to achieve specific goals for each public to achieve program objectives. The questions in this step are; what should we say, who should we say, who should, where, and how, when, and in what order?

4. Program evaluation. The final step in this process involves evaluating program preparation, implementation, and impact. Adjustments are made when the program is implemented based on feedback evaluations that evaluate the program's success or failure. After learning "What we do and how we do it the program keeps changing. This step summarizes the results of the evaluation and provides the basis for what follows.

\section{B. Public Relation}

Public relations is an art and a combination of management, communication, psychology, social and marketing, the formation of companies or institutions, ideas or ideas, names, and products that the general public likes and relies on. There are types of likes and dislikes that are known to be related to the target audience or stakeholders (Ruslan, 2013, p. $6)$ :

1. Those who know you and like you

2. Those who know you and do not like you

3. Those who neither you nor care you

\section{Public Relations Management}

Public relations management can be seen conceptually, functionally and its elements in activities influence public relations management in an organization. The goal is to create two-way reciprocal communication, build good relationships, and one-way persuasive communication, which aims to build mutual understanding, mutual respect, and support to create a positive image (Ruslan, 2016, p. 30), (Bakir et al., 2018).

\section{Communication Strategy through Instagram}

Rogers stated that the concept of communication strategy is designed to make more significant changes in human behavior by transferring new ideas. Meanwhile, according to Middleton, communication strategy is the best combination of all communication elements from the communicator, message, channel (media), receiver to influence (effect), which is designed to achieve optimal communication goals (Cangara, 2014, pp. 64-65).

According to R. Wayne Pace, Brent D. Peterson, and M. Dalla Burnett (Pace et al., 1979), communication strategy objectives are:

1. To ensure that the communicator understands and accepts the message.

2. How to receive messages correctly to determine acceptance.

3. Motivate yourself to action. Motivate yourself to action.

Make sure the communicator understands and accepts the message he receives. When the communicator has understood and accepted, the recipient must be promoted (to accept). Ultimately, messages must motivate action (to motivate action). Communication strategy, therefore, is the overall planning, tactics, and methods used to facilitate communication by taking into account all aspects of the communication process to achieve the desired goals (Abidin, 2015, pp. 115-116).

According to a previous study, managing marketing communication via Instagram is a strategic tool for informing, persuading, and reminding consumers about the products and services they offer. However, few empirical studies on the efficacy of Instagram as a marketing communication tool in managing digital marketing communication strategies with 
customers (Soedarsono et al., 2020, p. 108). Instagram's visual nature makes it highly appealing to brands. Through visual content, Instagram enables you to communicate with customers uniquely, differentiate yourself, become visible, build relationships with potential or existing customers, and create branding simultaneously (Jurisova, 2020, p. 119).

\section{METHOD}

\section{A. Research paradigm}

The paradigm in this study is post-positivism because, in research on the Implementation of Anticipation of the Spread of the Covid-19 by PT Kereta Commuter Indonesia, the researcher wants to see and describe the socialization carried out by PT. Kereta Commuter Indonesia's Corporate Communication is carried out directly and via@commuterline Instagram account.

\section{B. Research Approach}

PT. Kereta Commuter Indonesia's communication strategy approach in anticipating the spread of the Covid-19 is qualitative. Qualitative research seeks to explain the phenomenon as a whole through data collection. The population or sample size is not prioritized, even though the population or sampling is minimal. This type of research is a descriptive study. This research is designed to describe reality without explaining the relationship between variables. Based on this explanation, the qualitative approach in this study will be discussed and explained through participant observation and in-vehicle interviews regarding the communication strategies used by PT Kereta Commuter Indonesia.

\section{Research Informants}

This study selects key informants and informants using the purposive sampling technique. Purpose Sampling (purposive sampling) involves people who are selected by the researcher based on specific criteria based on the research objectives (Kriyantono, 2016, p. 158). The key informants in this study were PT. Kereta Commuter Indonesia's Corporate Communication, namely:

1. Rizkie Nugraha Ramadhan (33 years) conducts socialization directly at the train station and gets to know detailed information.

2. Janatta (26 years) socializes on @commuterline Instagram account

3. Ario Damsuki (27 years) conducts socialization in person at the train station

4. Yasmin Nur Fitriyani Azhar (23 years), commuter line passengers

5. Ratih Ghitahasya Shabrina (23 years), commuter line passengers

\section{F. Data collection technique}

Researchers have obtained data using the following techniques

1. In-depth interview (in-depth interview)

In-depth interviews collect information or data by meeting directly with informants to complete and detailed data. These interviews were conducted intensively (repeatedly) with high frequency. Besides, there are differences between respondents (people who were interviewed only once and informants (people the researcher wanted to know and understand and were interviewed several times) (Kriyantono, 2016).

2. Observation / observation

Observation is the activity of observing directly (without a mediator) an object to see carefully what a thing is doing. Researchers used participant observation by making direct observations by going to the station and seeing what PT Kereta Commuter Indonesia has done socialization. Researchers also carried out this observation by observing the socialization carried out by PT Kereta Commuter Indonesia by uploading on @ commuterline Instagram account.

3. Secondary Data

Secondary data is data collected from secondary or secondary sources. Because secondary data complements primary data, we need to be careful or choose secondary data unsuitable for our research (Kriyantono, 2016).

4. Documentation Method

The researcher data collection was carried out by collecting the necessary documents and data, namely data on the number of Covid-19 cases from the official website, information about the problem being studied on the online site, and uploading@commuterline Instagram account.

\section{E. Data Validity Techniques}

Triangulation of data sources was used in this study. Triangulation of data sources is triangulation to find the information in detail using different data collection methods and sources. Researchers used the data validity testing method by checking the information and information needed through interviews with key informants in this study, 
providing comments on @ commuterline Instagram account regarding socialization, and viewing papers. After finding the information and data needed through the methods and sources of obtaining the data, the researcher's information and data will be obtained in detail.

\section{RESULTS AND DISCUSSION}

Data collection through in-depth interviews with members of PT Kereta Commuter Indonesia's Corporate Communication team, specifically Rizkie Nugraha Ramadhan as the Media Relations Supervisor, Janatta as the Internal Documentation Program's staff member, and Ario Damsuki, as the Administration and Corporate Program's staff member. They are key informants in this study, as are Yasmin Nur Fitriyani Azhar and Ratih Ghitahasya Shabrina, as commuter line passengers. Internal communication strategies are also needed to maintain team solidarity and maintain good cooperation (Julianti \& Delliana, 2020). Retrieval of data using observation techniques by observing socialization content in anticipation of the Covid-19 spread through posts, Instagram stories, and Ig TV@commuterline. Data collection using documentation techniques is done by taking uploads about socialization on@commuterline Instagram account.

\section{A. Interview result}

Researchers conducted interviews with three PT. Kereta Commuter Indonesia Corporate Communication teams, namely Rizkie Nugraha Ramadhan, Janatta, Ario Damsuki, and two supporting informants who are commuter line passengers Yasmin Nur Fitriyani Azhar and Ratih Ghitahasya Shabrina. The communication strategy adopted by PT. Kereta Commuter Indonesia is to disseminate the anticipation of the spread of the Covid-19. This socialization was carried out to protect the company's internal and external parties and break the chain of the spread of the Covid-19 on public transportation.

PT Kereta Commuter Indonesia has conducted socialization by providing education on washing hands using soap and distributing masks for free at Tanah Abang Station, Juanda Station, Bogor Station, and several other stations simultaneously, which is a preliminary plan to disseminate anticipation of the spread of the Covid-19 at the beginning of February 2020. PT. Kereta Commuter Indonesia's Corporate Communication Team also conducted a campaign on the socialization of anticipation for the Covid-19 spread via@commuterline Instagram account and through banners at each station's health posts as an appeal to anticipate the spread of the Covid-19.

"So, after the chaos of the corona issue ... in this world, what we prepared in early February, we held socialization on how to wash clean hands, which is good and true with the distribution of masks. It was carried out in Tanah Abang, Juanda, Bogor, and several stations simultaneously at the beginning of February. " (Interview with Rizkie Nugraha Ramadhan, 30 April 2020).

"What is certain is how our communication strategy, uh ... from the employee side, from the KCI side, and the passenger side are both protected. This means that there is no distribution in the commuter line environment. So that is the way of our communication strategy" (Interview with Rizkie Nugraha Ramadhan, April 30, 2020). PT Kereta Commuter Indonesia (KCI) officially conducted socialization to spread the Covid-19 on February 3 and is currently being carried out. "Starting February 3, until now, it is still socializing" (Interview with Rizkie Nugraha Ramadhan, April 30, 2020).

"Yes, the election was due to more users than other stations. So we are, if the socialization, it is better to see more people, that is why we give him the station, the passengers must be more crowded "(Interview with Ario Damsuki, April 30, 2020).

"We go through the mass media, social media, we put banners at the station, we post information on the train through the PPK, at the station through the announcer" (Interview with Rizkie Nugraha Ramadhan, April 30, 2020).

The results of the interviews in this study were that PT. Kereta Commuter Indonesia implemented a communication strategy by disseminating the anticipation of the Covid-19's spread by conducting a preliminary plan for socialization by providing education to wash hands using soap and distributing masks for free to commuter line passengers. PT. Kereta Commuter Indonesia conducted a campaign regarding Socialization directly at the station and using social media,@ commuterline Instagram account, to reach all people quickly and have a message to convey. 


\section{B. Observation Results}

We observe@commuterline Instagram account in creating awareness of the Covid-19 spread, starting from providing education about washing hands using soap to conduct this socialization. Researchers made observations regarding the socialization of anticipation for the spread of the Covid-19 through @ commuterline Instagram account in the form of posts, Instagram Stories, and Instagram TV, aiming to provide education and appeal to all people to be more concerned aware of anticipating.

\section{Documentation Results}

Content on@commuterline Instagram account regarding the socialization of anticipating the Covid-19 spread in the form of Instagram stories, Instagram TV, and posts.

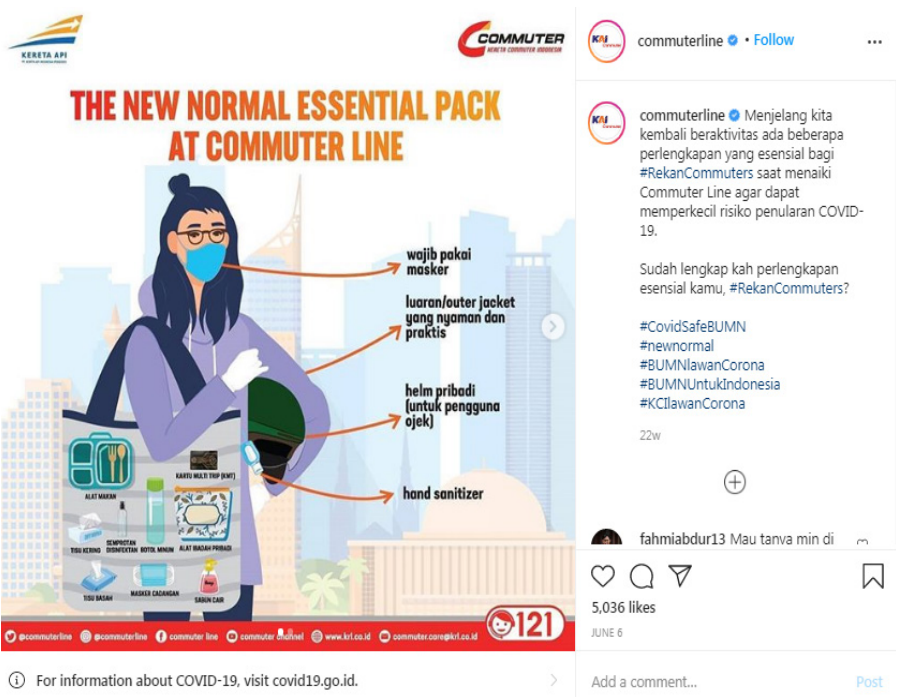

Fig. 2 Posts about socializing anticipation of the spread of the Covid-19 Source: (Commuterline Instagram Account, 2020)

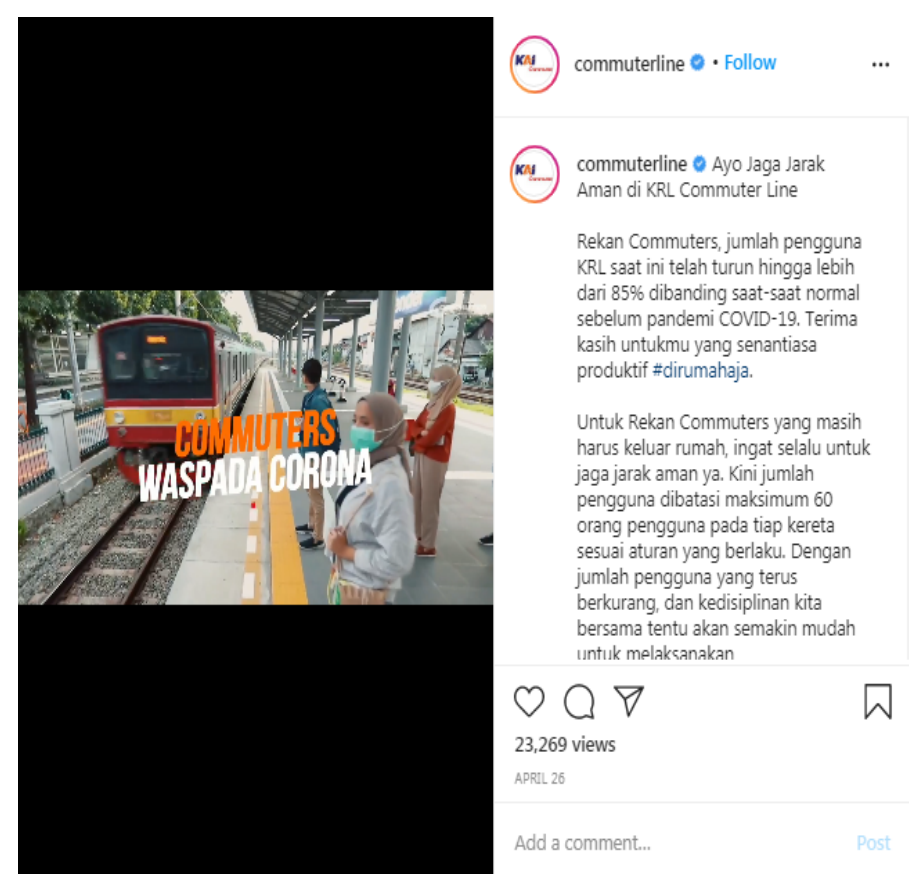

Fig. 3 Instagram TV regarding socialization in anticipation of the spread of the Covid-19 Source: (Commuterline Instagram Account, 2020) 


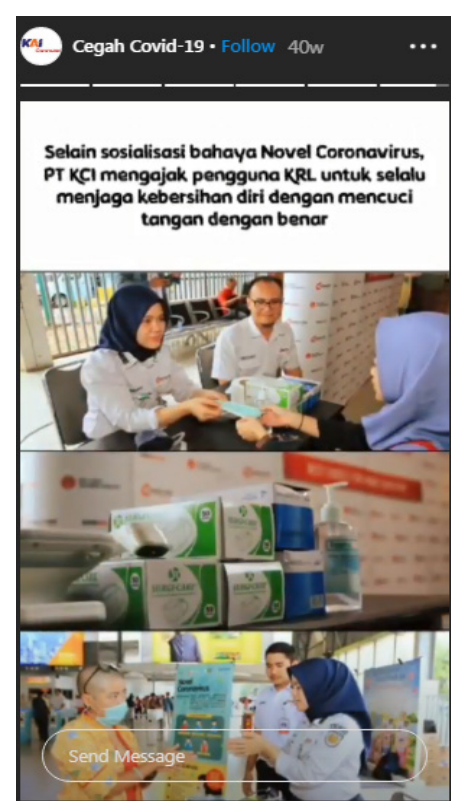

Fig. 4 Instagram story about education on washing hands using soap and distributing masks Source: (Commuterline Instagram Account, 2020)

\section{Discussion}

The communication strategy implemented by PT. Kereta Commuter Indonesia is by conducting socialization to anticipate the spread of the Covid-19. As said by Rizkie, who is one of the key informants in this study, the socialization was carried out to provide protection to internal and external parties of the company and to break the chain of the spread of the Covid-19 on public transportation. The communication strategy is carried out by conducting socialization through mass media, social media, and direct socialization. The choice of media to conduct the socialization is also based on reasons to make it easier to reach the community so that the socialization can run smoothly and directly. Rizkie also added that the communication strategy carried out by PT. Kereta Commuter Indonesia in socializing the anticipation of the spread of the Covid-19 is more effective when using social media because social media plays a vital role in helping to socialize. While social media can be an effective tool for communicating information about the Covid-19 for public health awareness and intervention, it also poses a risk due to the confusion and uncertainty caused by misinformation, disinformation, and misinformation, as evidenced by the growing infodemic that accompanies a contemporary epidemic or pandemic (Cinelli et al., 2020; Mohamad, 2020).

The researcher analyzed in this study using the Cutlip and Center theory regarding the four steps of the PR practitioner problem-solving process written by Broom and Sha. Based on the analysis carried out, it can be described as follows:

\section{Defining the problem (or opportunity)}

This stage is the first step that must be prepared by public relations when want to do the problem-solving process, according to the interviews conducted by researchers with the Corporate team of PT. Kereta Commuter Indonesia communication, the number of patients continues to rise due to the spread of the Covid-19 in Indonesia and the discovery of the first officially announced case of Covid-19 infection by President Jokowi on March 2, 2020. As stated by Rizkie, a key informant in this study, PT. Kereta Commuter Indonesia has prepared plans for conduct socialization by providing handwashing education using soap and distributing free masks to commuter line passengers at Tanah Abang Station, Bogor Station, Juanda Station, and several other stations on February 3, 2020. PT. Kereta Commuter Indonesia also conducted a campaign regarding socialization in anticipation of the Covid-19's spread on @commuterline Instagram account and through banners at health posts in 30 stations. PT. Kereta Commuter Indonesia is preparing to socialize anticipation of the spread of the virus corona to external parties and internal parties. The socialization is prepared by providing a hand sanitizer at some point in the company, distributing masks to all employees, and socialization is through printed media (magazines) and digital ones intended for PT. Kereta Commuter Indonesia internals. Preparations made by PT. Kereta Commuter Indonesia is the beginning of program planning to disseminate anticipation of the Covid-19's spread.

\section{Planning and programming}

After explaining the situation at this stage, it is the first step to making strategic decisions according to planning and program to be carried out. After making a preliminary plan, determine the communication strategy carried out in the socialization anticipating the Covid-19's spread. PT. Kereta Commuter Indonesia has made every commuter line passengers obey rules that will be disseminating in anticipation of the Covid-19's spread. Due to the spread of the Covid-19 
in Indonesia has been massive, so regulations are applied in conducting outreach to anticipate the spread of the Covid-19 by checking body temperature for every passenger who wants to enter the station, must use masks to all parties (internal and external parties) if passenger want to be in the area around the station, applying physical and social distancing by installing mark a minimum distance of 1 meter, and add a portable sink to make it more prioritizing washing hands using soap and water. Not only do commuter line passengers comply with these regulations, but all PT. Kereta Commuter Indonesia also must comply with the SOP that was implemented before the socialization. These are blood pressure checks, have had enough rest, and employees. Passenger service must wear gloves and providing an isolation room at each station. This step is carried out as one precaution if certain events lead to virus infection corona.

\section{Taking action and communicating}

At this stage, what must be done is to implement a communication strategy in the socialization of anticipation for the spread of the Covid-19 by PT. Kereta Commuter Indonesia and how to choose the proper communication to convey anticipatory socialization Covid-19 to all parties (internal and external). When an official case of a patient infected with the Covid-19 in Indonesia was found undertaken by PT. Kereta Commuter Indonesia is to prepare for the socialization in a way provide education on washing hands using soap and distributing masks for free as a way to implement the communication strategy carried out in socializing anticipation of the spread of the Covid-19. When doing socialization, anticipating the spread of the Covid-19 requires the involvement of internal parties (employees) and external parties commuter line passengers so that the socialization is successfully done according to the objectives that have been set. Not only involving the Corporate team Communication only, but also involves other parties, especially parties who work on the front liner, and require passengers' involvement. PT. Kereta Commuter Indonesia's Corporate Communication states that it is necessary to involve all parties because they can work together in order to carry out the socialization that has been planned.

\section{Evaluating the program}

The final stage in the problem-solving process steps carried out by public relations is evaluating anticipatory socialization programs the spread of the Covid-19 by PT. Kereta Commuter Indonesia according to its communication strategy. Corporate team Communication of PT. Kereta Commuter Indonesia that the socialization was adequate or not has been done by PT. Kereta Commuter Indonesia can be seen from the behavior of commuter line passengers and employees whether they obey the applicable rules in anticipatory socialization the spread of the Covid-19 based on regulations from the Government. Mandatory regulations must be obeyed by all internal parties (employees) and commuter line passengers. One of them is to use a mask when in the area around the station, and this has proven to be effective because the rule was successful in being implemented to all parties. Apart from that, there was socialization about handwashing education using soap has also been successful because PT. Kereta Commuter Indonesia has provided an additional portable sink at each station. Following Rizkie's hope that the community has no outside interests house to stay at home can be realized because of the current commuter line passengers service. Most of the Government's WFH policies are simply workers who cannot do WFH and people who have urgent needs only. Apart from that, Janatta PT. Kereta Commuter Indonesia's Corporate Communication team, who was one of the informants the key in this study, explains that the socialization carried out on@commuterline Instagram account can be effective. These commuter line passengers have started to know and obey physical distancing by obeying the markers with a minimum distance of 1 meter.

PT. Kereta Commuter Indonesia also applies social distancing as a form of application PSBB follows the governor of DKI Jakarta's regulations. The application implemented in the Covid-19's socialization of anticipation spread in limit the number of commuter line passengers on each training series with quotas totaling 60 people. However, the restriction on the number of commuter line passengers has been changed since Instagram posts @ commuterline to 74 people in a series of trains. Rizkie said that the officers on guard near the train door would usually stop commuter line passengers who will get on if the train conditions are met according to the quota enforced. However, one of the supporting informants in this study, a commuter line passengers, namely Ratih, who has related pros and cons restrictions on the number of passengers being enforced by the PT. Kereta Commuter Indonesia, is one of the socialization to anticipate the spread of the Covid-19. Ratih has pro responses with the implementation of limiting the number of user quotas commuter line in a train series carried out by PT. Kereta Commuter Indonesia at the start of the Covid-19 pandemic because it coincides with the company that enforces its Work From Home policy. Drastic decrease in the number of commuter line passengers followed the policy.

Meanwhile, the counter-response delivered by Ratih was since the transition period becomes new normal with the enactment of one user restriction. A series of trains with a total quota of 74 people is considered ineffective because there is a build-up of commuter line passengers for current passengers waiting in line to enter the station and train. Making social distancing applied in the socialization was not applicable. One of the socializations to anticipate the Covid-19's spread was PT. Kereta Commuter Indonesia reduces operating hours, which are initially from 06:00 - 18:00 to 04:00 - 21:00. Yasmin as the supporting informant in the research This argues that he supports the efforts that PT. Kereta Commuter Indonesia has made, but implementing reduced operating hours can also make it difficult for para commuter line passengers. With the change in operating hours, Yasmin is one of the supporting informants in this study. This less 
effective considering the growing number of commuter line passengers, especially since the new normal transition period, especially during the office hours peak ranging from 16:00 - 17:00. It will make 61 the accumulation of the number of commuter line passengers at stations and challenging to implement social distancing and physical distancing.

According to Janatta, one of the key informants, the responses are pros and cons given by commuter line passengers related to the rules applied in the socialization anticipating the spread of the Covid-19, which can be adjusted and carried out compared to the beginning of the socialization. Janatta also said that the application of social distancing and PSBB rules carried out in outreach anticipation of the spread of the Covid-19 has an impact, which is to experience a decline in revenue and a drastic reduction in the number of passengers as much as $90 \%$. However, this indicates that PT. Kereta Commuter Indonesia's socialization is carried out and accepted by the community.

\section{Implementation of Anticipation Socialization of Covid-19 Spread}

On February 3, 2020, PT. Kereta Commuter Indonesia made a preliminary plan to conduct socialization in anticipation of the spread of the Covid-19, which aims to provide education by socializing, washing hands with soap to and distributing masks for free to commuter line passengers at Tanah Abang Station, Bogor Station, Juanda Station, and several other stations. The socialization of the anticipation of the spread of other Covid-19es carried out by PT. Kereta Commuter Indonesia, namely conducting campaigns to anticipate the spread of the Covid-19 using banners at health posts located at each station, checking body temperature using a thermometer and thermoscreen before entering the station, giving advice through announcers and PPK, applying physical distancing and social distancing by providing markers with a minimum distance of 1 meter, applying the mandatory rule to use a mask if you are in the station area and want to use commuter line, providing hand sanitizers and adding a portable sink, imposing a quota on each series of trains which initially numbered 60 people to 74 people to implement PSBB regulations from the Government, washing commuter line facilities regularly which is divided into two stages, namely interior (ceiling, grips, air conditioning, chairs, and floors) and exterior (outside walls of doors and windows), spraying using disinfectant fluid before or after the commuter line facility operates every day, keeps trains clean by using the services of On Trip Cleaning (OTP) officers when they are working, and provides temporary isolation rooms to anticipate if there are passengers who have characteristics or are infected with the Covid-19 before being handed over to health officials.

According to one of the key informants in this study, Ario, at first, the socialization of anticipating the spread of the Covid-19 was only carried out at certain stations with the highest number of passengers every day. However, because the Covid-19's spread is getting faster, socialization has been carried out at all stations. Socialization of the Covid-19's spread has also been intensively carried out directly and continuously by using various methods such as mass media, social media, banners at stations, and information on trains through PPK at stations through announcers. With the socialization of the anticipation of the spread of the Covid-19, the PT. Kereta Commuter Indonesia Corporate Communication team, who were the key informants in this study, namely Rizkie, Ario, and Janatta, have the hope that commuter line passengers will be more alert, care and obey the rules and advice given through this socialization. According to researchers, this is following the understanding of socialization, namely studying and understanding existing social values and norms.

Through this socialization activity, the PT. Kereta Commuter Indonesia Corporate Communication team, namely Rizkie, Janatta, and Ario, have a message to convey through these activities. Namely, PT. Kereta Commuter Indonesia has made efforts to follow government regulations. PT. Kereta Commuter Indonesia is intensively carried out to remind the public, especially commuter line passengers, to be more alert and to care.

\section{Social Media Used To Socialize}

PT. Kereta Commuter Indonesia also conducts socialization to anticipate the Covid-19's spread through social media, namely the@commuterline Instagram account. PT. Kereta Commuter Indonesia carried out the socialization through posts, Instagram stories, and Ig TV. The socialization was carried out through the @commuterline Instagram account to appeal to all people, especially commuter line passengers, to be more alert and concerned about breaking the chain of spreading the Covid-19. Besides, socializing on the @ commuterline Instagram account is expected to provide education and information to reach all people, especially commuter line passengers. The socialization also aims to protect all internal and external parties of PT. Kereta Commuter Indonesia.

According to Rizkie, one of the key informants in this study using the According to the Cutlip and Center Theory, therecommuterline Instagram account, social media plays an essential role in disseminating information and socializing. According to Rizkie, almost $70-80 \%$ of commuter line passengers are of productive age, therefore socializing the anticipation of the Covid-19's spread through posts, Instagram stories, and Ig TV on @commuterline Instagram account, the effect can be seen directly. 


\section{CONCLUSION}

Based on researchers' findings, one of the communication strategies was carried out by PT. Kereta Commuter Indonesia is to socialize the anticipation of the spread of the Covid-19. The communication strategy applied is related to the four-step problem-solving process according to the Cutlip and Center Theory written by Broom and Sha and has research results, namely to protect internal and external parties of PT. Kereta Commuter Indonesia, provide education, and give appeal to the public, especially commuter line passengers to be more aware, be alert and care to anticipate the spread of the Covid-19.

There are four steps in the process of solving the problems of public relations practitioners according to the Cutlip and Center Theory, namely based on the current conditions and conditions, the spread of the Covid-19 in Indonesia has increased the number of Covid-19 infection patients, therefore PT. Kereta Commuter Indonesia provides education on washing hands using soap and distributing masks accessible to commuter line passengers to disseminate the anticipation of the spread of the Covid-19, then PT. Kereta Commuter Indonesia determines the communication strategy that is implemented through the socialization of anticipating the spread of the Covid-19 by enforcing mandatory rules for wearing masks, checking body temperature, and complying with the minimum distance markers of 1 meter as, in the form of social and physical distancing implementation, the socialization carried out by PT. Kereta Commuter Indonesia has also campaigned directly and through the @commuterline Instagram account with the hope of reaching all parties so that the socialization carried out can run as intended because of involvement from all parties is what made the socialization successful, after taking these steps, the last thing that can be done is to evaluate to assess the preparation, implementation of the socialization, and the resulting impact based on the feedback provided by commuter line passengers whether the socialization has been adequate or not.

The campaign carried out by PT. Kereta Commuter Indonesia, applying the mandatory rules to use masks, checking body temperature using a thermometer and thermoscreen, giving advice through announcers, conducting socialization through banners at health posts at stations, implementing physical distancing and social distancing by giving markers with a minimum distance of 1 meter, providing hand sanitizers and adding a portable sink, implementing PSBB rules with an initial quota of 60 people and now 74 people in each training series. Besides, PT. Kereta Commuter Indonesia also performs routine washing of commuter line facilities on the interior (ceiling, grips, air conditioning, chairs, and floors) and exterior (exterior walls of doors and windows), sprays disinfectant liquid on commuter line facilities every day, always keeps the train clean, which is currently operating using the services of On Trip Cleaning (OTP) officers, and providing temporary isolation rooms for commuter line passengers infected with the Covid-19 to anticipate events having characteristics or being infected with the Covid-19.

\section{REFERENCES}

[1] Abidin, Y. Z. (2015). Manajemen Komunikasi: Filosofi, Konsep, dan Aplikasi. Pustaka Setia.

[2] Alodokter. (2021). Virus Corona. Alodokter.

[3] Aulia, S. T. (2020). Diskursus Penanganan Covid-19 Oleh Pemerintah Pusat Dan Daerah: Efektifkah Kebijakan Pembatasan Sosial Berskala Besar (Psbb) Diterapkan?. Universitas Padjadjaran.

[4] Bakir, V., Herring, E., Miller, D., \& Robinson, P. (2018). Organized Persuasive Communication: A new conceptual framework for research on public relations, propaganda, and promotional culture. Critical Sociology, 45(3), 311328. https://doi.org/https://doi.org/10.1177\%2F0896920518764586

[5] Broom, G. M., \& Sha, B.-L. (2013). Cutlip and Center's Effective Public Relations (11th ed.). Pearson.

[6] Cangara, H. (2014). Perencanaan dan Strategi Komunikasi. Rajawali Pers.

[7] Cinelli, M., Quattrociocchi, W., Galeazzi, A., Valensise, C. M., Brugnoli, E., Schmidt, A. L., Zola, P., Zollo, F., \& Scala, A. (2020). The COVID-19 Social Media Infodemic. Scientific Reports, 10(16598). https://doi.org/https:// dx.doi.org/10.1038\%2Fs41598-020-73510-5

[8] Commuterline, I. (2020). Tips Pencegahan Penyebaran Virus. Instagram.

[9] Dewi, R. K. (2020, October). Perjalanan Kasus Virus Corona di Indonesia. Kompas.Com.

[10] Fitriani, F. F. (2020). DKI Jakarta PSBB: Pekerja Sektor Dikecualikan Tetap Harus Patuhi Social-Physical Distancing. Bisnis ID.

[11] Hairami. (2020). Apa itu COVID-19? Begini Penjelasan Jubir Pemerintah Terkait Virus Corona. Ivooxid.

[12] Instagram. (2020). @commuterline Instagram account.

[13] Julianti, I., \& Delliana, S. (2020). Rebel Together Sebagai Strategi Komunikasi Pemasaran Digital Madformakeup Di Tengah Pandemi COVID-19. Communicatus: Jurnal Ilmu Komunikasi, 4(2), 207-228. https://doi.org/https:// doi.org/10.15575/cjik.v4i2.9686

[14] Jurisova, V. (2020). Building Brand Identity on Instagram. Proceedings of the 7th European Conference on Social Media ECSM 2020, 119-126. 
[15] kawalcovid. (2019). Pantau Data Corona Indonesia. Katadata.

[16] Kriyantono, R. (2016). Teknik Praktis Riset Komunikasi. Kencana Prenada Media Group.

[17] Maharani, S. A., \& Siahaya, I. A. (2016). Evaluation of Strategies and Implementation of Starbucks Coffee to Establish The Image of Indonesian Coffee. Jurnal InterAct, 5(1), 28-34. https://doi.org/http://dx.doi.org/10.36388\%2Fia. v5i1.769

[18] Mohamad, S. M. (2020). Creative Production of 'COVID $\square 19$ Social Distancing' Narratives on Social Media. Journal of Economic and Human Geography, 111(3, Special Issue: The Geography of the COVID $\square 19$ Pandemic), 347-359. https://doi.org/https://doi.org/10.1111/tesg.12430

[19] Pace, R. W., Peterson, B. D., \& Burnett, M. D. (1979). Techniques for effective communication. Addison-Wesley Publishing Company.

[20] Ruslan, R. (2013). Kiat dan Strategi Kampanye Public Relations. Raja Grafindo Persada.

[21] Ruslan, R. (2016). Manajemen Public Relations dan Media Komunikasi: Konsepsi dan Aplikasi. Raja Grafindo Persada.

[22] Sari, F. P., \& Nugrahani, R. U. (2019). Strategi Tata Kelola Komunikasi Krisis Humas Pemerintahan Kabupaten Kuningan Jawa Barat dalam Menghadapi Krisis Governance Crisis Communication Strategy of Public Relations in The District of Kuningan in Dealing With Crisis. Channel Jurnal Komunikasi, 7(2), 89-96.

[23] Soedarsono, D. K., Mohamad, B., Adamu, A. A., \& Pradita, K. A. (2020). Managing Digital Marketing Communication of Coffee Shop Using Instagram. International Journal of Interactive Mobile Technologies (IJIM), 14(5), 108-118. https://doi.org/https://doi.org/10.3991/ijim.v14i05.13351

[24] Undang-Undang Republik Indonesia Nomor 24 Tahun 2007 (n.d.). 
